\title{
POLITICAL AND PARTISAN IMPLICATIONS OF STATE LEGISLATIVE APPORTIONMENT
}

\author{
Charles W. Shull*
}

The theme of the political and partisan implications of state legislative apportionment poses a challenge simultaneously with the sounding of a warning tocsin. The challenge lies chiefly in the need to view the forest of states as a whole in terms of their representative system; the warning lies in the necessity of considering individual state situations as significant in making up the forest without becoming appalled by the character and particularities of the separate trees.

Reapportionment long since has become a chronic problem within the American states. Like all chronic situations it has been subjected to much critical analysis; like many such conditions the lack of ready, facile solutions has been bewailed or shrugged off as mood and time have seemed to dictate. It is not the task of this paper to chronicle the individual symptoms of this chronic malaise or disease; what is called for is a discussion of the social, economic, and political results and significances of a presumably epidemic condition.

Consequently the concern in this article will not be with the details of state representative systems, nor will there be any treatment of the merits or shortcomings of those individual legislative setups. Certainly it will be necessary to mention such detail in order to evaluate and assess specific representative devices. There will not however be the repetition of constitutional or statutory provisions so vital to an exposition of the apportionment process at the level of the American states.

Trite and banal as it may seem, the process of the apportionment of the members of the American state legislatures has political and partisan implications simply because these positions are representative and are also elective. Under those circumstances it would seem to be inevitable that there would be political significance at all stages of the apportionment process.

Approximately 7,500 individuals constitute the total membership of all American state legislative bodies. As has been detailed in an earlier section of this symposium, they have been distributed throughout the separate states in such a way that the 43 in the single chamber of Nebraska represent the minimum elected in any state; at the other end of the scale are the 433 in the two chambers of New Hampshire. All of these legislators, let it be repeated, are elective in terms of their acquisition of

- B.A. 1926, Ohio Wesleyan University; M.A. x927, Ph.D. x929, Ohio State University. Professor of Government, Wayne University. Member of Committee on American Legislatures, American Political Science Association. Author, American Experience With Unicameral Legislatures (I937); ReAPPORTIONMENT OF THE LEgISLATURE IN Michigan (1947); (with Roucek and Haszar) INTROdUCtion to Political Science (1950); (with Comfort and Knapp) Your Government (I95I). 
office, and justly so in terms of their character as representatives serving their respective constituencies.

This political significance of the elected representative is cast in diverse molds. One of the most famous of all is the ever fertile discussion as to the duty of the representative-is he to vote as his conscience and conviction and knowledge direct him or is he to mirror only the mandate of his constituents? Leaving this aside, let us plunge on to the next point. At what levels of the American political system and its partisan tableaux does the elective member of an apportioned state legislature begin to become political and to exude, as it were, political and partisan implications of significance? The answer is at a fairly early stage; in fact, at the level of the American county, or the district as a combination of counties.

One of the basic determinants of this factor lies in the fairly general use of the county in the process of districting for electoral purposes, if not the employment of the county as an element in the process of apportionment. It will be necessary to explore briefly the ways in which counties are utilized in the process of arranging for legislative structure and representation within the American states. ${ }^{1}$

In all but a handful of states, counties do play a role in the creation of a representative arrangement and districting. Delaware makes its entire legislative apportionment for both chambers, by means of a set of constitutional provisions established in 1890 , and possessing only three counties, patently can scarcely find an effective way to employ them in structural arrangements for purposes of legislative representation. New Hampshire and Rhode Island prefer to use their basic governmental unit-the town-throughout their entire representative system rather than employ in any way their counties which are few in number. Fortyfive of the states make some use of their counties in their apportionment processes.

Counties may be treated as integral components of a representative system in the same manner as are the states in the case of the United States Senate. Thus New Jersey and South Carolina allot one senator to each county, ordaining equality of treatment for each such unit regardless of obvious differences in character and status. Idaho also makes reference to a senate composed of one member from each county, and does emerge with an upper chamber of 44 members, equal in number to its counties. While Nevada speaks of its counties as units to which legislative seats in both chambers are to be allocated in terms of population, the practical effect of its statutes in connection with its senate allows a single senator for each of its 17 counties. Maryland approaches this norm for its senate, for after providing that there shall be 6 legislative districts within Baltimore county from each of which a single senator shall be selected, the remaining constitutional provisions ordain that a separate senator shall be chosen by each of the remaining counties, which number 23. Arizona temporizes with this method of treating counties, establishing them

\footnotetext{
${ }^{2}$ For this portion of the study I am paralleling my treatment of the same subject in Shull, Counties in the Apportionment Process, 6 THE COUNTY OFFICER 247 (Oct. 1951).
} 
as units of senatorial representation, and then allotting one or two senatorial seats to each without reference to any apparent formula.

A number of states use their counties as units to which senators are allotted in terms of population. In Maine all counties enter into the construction of the senate. Vermont apportions its senators to the counties according to population, regard being had for counties with the largest surpluses, but each county must have one senator. Wyoming also flirts with this practice, having initially alloted its senators upon a proportional basis to each of its counties, although later provision has been made for the creation of legislative districts of two or more counties. In Ohio the alignment of counties into senatorial districts has been constitutionally fixed, and such districts do not fall apart with the lapse of each decennial period, but continue in existence and become the basis for succeeding apportionments. Districts thus will always be composed of entire counties.

Seven states make provision for the apportionment of a variable number of senators to their respective districts. These are Kansas, Oklahoma, New York, Arkansas, Colorado, Pennsylvania, and Louisiana. Arkansas and Colorado stipulate that no county may be divided in the formation of senatorial districts. Pennsylvania, New York, and Oklahoma set down in their constitutions the circumstances under which seats in their senate are to be allotted, and govern those instances in which counties or portions of counties entitled to two or more senators are to be divided. Louisiana limits the possibility of internal partition of its parishes for representative purposes, or rather senatorial apportionment, to the single parish of New Orleans. Pennsylvania and New York establish maximum limits upon the number of senators which any county or special area may attain.

The next group of states to be considered follows the principle of equal senatorial representation in terms of the number assigned to each district. Twenty-seven states comprise this group, although Montana approaches the possibility of equal county representation by decreeing that no county may have more than one senator.

West Virginia authorizes the division of the state into senatorial districts from each of which two members are to be chosen; where two or more counties are included in such a senatorial district, both members cannot legally come from the same county. The remaining 25 states $^{2}$ adhere to the principle of a single member per district in their senates. In general these states do not permit a county to be divided in the formation of individual districts unless as in Michigan, Missouri, Virginia, and Wisconsin, the area in question is equitably entitled to two or more members. Thus in this last group of states the rule is that of a single member district, but that selfsame district may be composed of an entire county, two or more counties, or a part of only one county.

Before passing to the consideration of the lower chambers, attention should be

s Alabama, California, Connecticut, Florida, Georgia, Illinois, Indiana, Iowa, Kentucky, Massachusetts, Michigan, Minnesota, Mississippi, Missouri, New Mexico, North Carolina, North Dakota, Oregon, South Dakota, Tennessee, Texas, Utah, Virginia, Washington, and Wisconsin. 
given to the unicameral senate of Nebraska. Here there is provision for legislative districts of any one of these types-single-county, combinations of counties, or portions thereof when the county in question is large enough in terms of population to merit two or more members in the unicameral body of this state legislature.

Delaware makes its house apportionment and districting by constitutional provisions as is the case with its senate. A number of the New England states employ governmental units other than their counties in distributing the seats in their lower chambers. These are Connecticut, New Hampshire, Rhode Island, and Vermont, where the New England town has been utilized as the primary unit of representation whether upon a basis of equality of political unit or proportionately upon population. Two states, Illinois and North Dakota, use districts which have been established for the purpose of electing their senators as a device for the solution of the problem of apportioning their house of representatives. Thus Illinois flatly gives three representatives to each senatorial district, while North Dakota allows the number to vary.

The remaining states fall into two groups. The first of these categories proceeds to compose its representative districts at the level of the lower chamber by the application of various apportionment formulas in such a way as to produce three generic types of districts. These are (a) single-county districts, (b) combinations of two or more counties, and (c) parts of counties where two or more seats are allotted to an individual county. Twenty-one states fall into this first group. ${ }^{3}$ In some of these, Kansas for example, the scheme may approach virtual use of counties, or parts of counties only, in practice, although there is no specific guarantee of the individual status of each county.

The second group is composed of those states where the lower chamber apportionment emphasizes the role of the county. In this type of representative system only two kinds of districts may possibly be created-single-county ones, or portions of counties where the area is entitled to two or more members. Nineteen states fall into this class. ${ }^{4}$

Florida and Georgia adopt a device whereby their counties are ranked in order of population. Then these counties are divided into three unequal groups to each of which members are allocated equally in descending arithmetical order. The remaining states in this class provide in each instance that all counties must be given at least one member, although there are variations and exceptions to be noted in several states' practice. Maryland gives two each as minimum, while Pennsylvania prescribes a variable number, ranging from one to four. Arizona allots its members of the house of representatives upon the basis of units of votes cast for governor; this

\footnotetext{
${ }^{3}$ These states are: California, Colorado, Idaho, Indiana, Kansas, Kentucky, Michigan, Minnesota, Montana, Nevada, New Mexico, Oklahoma, Oregon, Tennessee, Texas, West Virginia, South Dalkota, Virginia, Washington, Wyoming, and Wisconsin.

Florida, Georgia, Alabama, Arizona, Arkansas, Iowa, Louisiana, Maine, Maryland, Massachusctts, Mississipi, Missouri, New Jersey, New York, North Carolina, Ohio, Pennsylvania, South Carolina, and Jtah.
} 
unit of representation is one member for each 2,500 votes or major fraction thereof.

This presentation of the use of the county in the apportionment process has been made with this precise objective-to show that in the general process of electing our representatives, we force them to become subsidiary in their appeal and thus tarnish and blunt the glitter and importance of their offices. Inescapably the political success of the would-be member of a state legislature is hitched to his party's fortunes in all but Minnesota and Nebraska, ${ }^{5}$ and also is indubitably geared to partisan activity at the county level. The burden of the argument here runs in this wise; so long as great dependence is had upon the county or some grouping of counties as the measure in any way of the electoral unit for our state representatives and our state senators, just that long there will be a politicizing of their character beyond that required by the recognition of the essentially representative nature of the political posts they seek.

Virtually all-there are exceptions-of the counties will elect as their own officers a series of persons to serve variously as sheriffs, commissioners or supervisors, county auditors, treasurers, recorders or registers of deeds, surveyors or drainage commissioners, prosecutors, and coroners. Legislative candidacies are unavoidably linked with the fate of county tickets. Would-be legislators have, in many instances, to accommodate their campaign plans to the general type projected for all and sundry county offices and candidates.

State representative systems are then related to the individual political patterns of each state for which they have been created. Lacking the dramatic character assigned to policy-making posts under the concept of the short ballot, these positions within American state legislatures find their fate in a diminution of their individual importance intrinsically, while their political and partisan significance sets them in the framework of the county or district party organization, and renders them less significant in the statewide sense, and much more vital in the local or electoral sense.

Local traditions embedded in party practice at the county or district level also affect the freedom of candidacy, the chance at a significant tenure, and the opportunity for the development of leadership. Rotation of the office from region to region; rotation in terms of consecutive elections or candidacies permitted to individuals; the relation of political success to definite ascension rung by rung of a locally constructed ladder of political prowess and preferment-all tend likewise to envelop the state representative system with incrustations about which little is actually known in terms of operation.

Reiteration would emphasize in this section of this article these basic points. First, the office of representative or senator at the state level is innately political in character by reason of being a representative position and because it is elective in nature. Second, the American states must conjure with the county in the process of apportionment no matter what the formal representative basis may be. Conse-

\footnotetext{
- These states are ostensibly non-partisan as to the method of electing their senate in Nebraska and house in Minnesota.
} 
quently one range of political and partisan implications of state legislative apportionment stems directly from the linkage of the electoral details of representation to the political features of the county party organization, district committee, or courthouse ring.

But this is not the only way in which otherwise latent implications of state legislative apportionment may be manifested. Obviously the entire atmosphere in which these politically significant legislators set to work conditions their role and its distinctive attributes. Consideration is not to be given to the architecture of legislative chambers or to the staffing of these agencies either with personnel or working space in which to function. Nor are we thinking in terms of the procedural milieu within, and with which, any legislative body must gird itself in order to function.

The action of legislatures involves the process of compromise and reconciliation to a very considerable degree. Coalescence upon some presumably defensible measure has to be achieved if the process of legislation is to attain fruition in any particular instance. What concerns us at this point is not a philosophical discussion of the legislative process in its semantic or logical phases, or even in the cross bargaining stages that must be indulged in to attain agreement as to the fate of a proposed law or constitutional provision. What does concern us are in effect the breaking points at which such determination of the fate of a measure can or must occur within the scope of legislative decision.

There are four places or stages in the entire legislative process where such numerical figures become critical, and whatever point is established arithmetically on each of these stages has political and partisan implications for the fate of state legislative apportionment. These are (a) passage of measures for normal application of such customary effective date as may be constitutionally provided; (b) passage as an emergency measure to be given immediate effectiveness; (c) action of the legislature on gubernatorial vetoes either item or general; and (d) actions relating to constitutional revision and amendment.

Obviously our state legislatures use a majority vote of some kind as the measure of the passage or rejection of a bill. But what majority, or rather majority of what? Several practices can be noted among the states. A number of states follow the usage of the national Congress, in that a majority of the members present and voting on a measure are sufficient to conclude action thereon. In all such cases a quorum of one-half of the membership is required to be present in order to validate the action. States pursuing this practice include Alabama, Connecticut, Florida, Maine, Massachusetts, Mississippi, Montana, New Mexico, North Carolina, Rhode Island, South Carolina, Texas, Vermont, and Wyoming. ${ }^{*}$ It should be noted that Vermont requires a larger majority on some types of measures than on others. Arkansas demands that a majority of the membership of each house approve a bill prior to passage; ${ }^{7}$ so do New Jersey and Tennessee. Kentucky and Virginia specify

${ }^{\text {G See }} 8$ The Boox of the States, I950-195I 116 for table giving this data.

TIbid. 
that two-fifths of the elected members of each house must be present, and that the bill will carry upon a favorable majority of those voting. New Hampshire indulges in a complicated formula. A majority of the members of its house constitutes a quorum for doing business. But when less than two-thirds of the representatives elected shall be present, the assent of two-thirds of these is necessary to render their acts and proceedings valid. Not less than I3 of the New Hampshire senators shall make up a quorum for doing business, but when less than 16 are actually present, the assent of 10 is necessary to render their actions and procedure valid. The other 28 states introduce the requirement that a majority of all members elected to each individual chamber must vote in favor of a measure before it can be deemed passed.

The next matter of import in terms of majorities, or prescribed agreement points, in terms of the raw mechanics of legislation, concerns itself with what are known as emergency measures or measures to be given immediate effect. This is a problem encountered at the level of the states and not at the procedural level and pattern of the national Congress. That body, i.e., Congress, is not faced with either the constitutional requirement of a uniform effective date for all of its enactments, nor with the necessity of accommodating itself and its work to the institution of the referendum. The states generally face the first of these problems, and the group of them which also possess the institution of the referendum meet both of these limitations to legislative discretion as to the effectuation of a statute in terms of time. The chief method proposed for solution of this problem has been the device of the so-called emergency act given immediate effect. Since in virtually all instances the principal element of emergency inheres in the choice between the delayed date for initiation of enforcement enjoined by the constitution, or the election of the date of signature, fixation of the great seal of the state, and promulgation as marking the effective beginning of the measure's administrative history, this element of emergency frequently becomes one of confusion, misapprehension, and mystery.

If an emergency measure cannot be determined at the state legislative level on any other basis than the above, how do these bodies go about doing so? For many the answer is that discretion exists in them for this purpose. Should they decide upon an immediate effective date and declare it in either the preamble, a separate caption, or distinctly in the text of the statute, they may do so in the regular course of legislative activity, and without the requirement of an enlarged majority vote.

Another group of states choose to be more specific. They prescribe a fixed majority distinctly higher than that requisite for the passage of a bill in order that an early, immediate effective date may be given to a statute or law. By most of the constitutions of the states enjoining this practice, the necessary vote is usually de-

${ }^{8}$ I would so class the following states: New York, Pennsylvania, Arkansas, Mississippi, Louisiana, Maryland, Iowa, Wyoming, Idaho, Nevada, New Jersey, Kansas, Tennessee, Oregon, Montana, Washington, Minnesota, Vermont, Wisconsin, Rhode Island, New Hampshire, Georgia, Florida, Delaware, North Carolina, South Carolina, Indiana, Alabama, Kentucky, South Dakota, and Connecticut. This is determined upon the basis of their constitutions and their legislative rules. 
fined as two-thirds. There are variant interpretations however as to the base from which this two-thirds is to be taken. Massachusetts refers to two-thirds of the members of the house in question. Virginia demands a vote of four-fifths of the members present and voting to accomplish this purpose. Sixteen other states ${ }^{9}$ prescribe a two-thirds majority of all members elected to the particular chamber.

Veto provisions will next be scrutinized. North Carolina alone among the $4^{8}$ states does not make provision for the executive veto of legislation proposed by the law-making body of the state. The possibility of the veto of items in appropriation measures, or in rare instances items in so-called emergency or immediately effective acts, is found in all except the following states: Indiana, Iowa, Maine, Nevada, New Hampshire, North Carolina, Rhode Island, Tennessee, Vermont, and West Virginia.

Customarily an executive veto, whether of an item of a bill appropriating money or of an entire substantive measure, can be overridden by a larger majority in the separate chambers than that by which the proposed act passed in the first instance. The next point in the current discussion is an analysis of this enlarged and increased majority in order to displace the effect of an executive veto. Connecticut appears to have the most lenient provision-namely, that a majority of those present may act to override an executive veto. Alabama, Arkansas, Indiana, Kentucky, Tennessee, and West Virginia specify a vote equal to a majority of all elected members as necessary to displace the executive disapproval of the particular item or bill. Rhode Island decrees that the majority shall be three-fifths of those present, while Delaware, Maryland, Nebraska, and Ohio require this to be three-fifths of those elected to the chamber. Florida, Idaho, Massachusetts, Montana, New Mexico, Oregon, South Dakota, Texas, Vermont, Virginia, and Wisconsin follow what is essentially the national rule of two-thirds present and voting, assuming a quorum is on hand. The remaining 25 states apply the principle of a majority equal to two-thirds of members elected if a veto is to be overridden. ${ }^{10}$

Matters other than ordinary legislation are committed to the discretion and responsibility of our representative state legislatures. Constitutional amendment and constitutional revision may be initiated at this level of American state government. Here there will be treatment of two distinct processes. The first is that of the proposal of particular amendments to constitutions by action of the state legislatures; the second involves the procedures requisite to call in being, and to organize a revisory convention in the several states.

In each of these processes we encounter again this matter of a prescribed majority as requisite for the consummation of such actions as those just detailed. Forty-seven states have vested power to propose constitutional amendments in their

\footnotetext{
'The "two-thirds rule" states in terms of immediate-effect limits are: Utah, Missouri, California, Colorado, Oklahoma, Texas, West Virginia, Illinois, Ohio, Arizona, Nebraska, North Dakota, Michigan, New Mexico, and Maine, plus Massachusetts just cited with its reference to two-thirds of members of the house in question.

${ }^{10}$ For the practice of the states with regard to the votes on both general substantive vetoes and on itcm vetoes, see 8 THE Book OF THE STATES, I950-195I II7 for the table giving this detail.
} 
respective legislatures; New Hampshire is the lone exception. In general these elective, representative state legislatures are used only for the proposal of the amendment, although in Delaware the power of ratification vests in the body immediately subsequent to that which proffered the measure for consideration as a change in the fundamental law of the state.11

In terms of the voting majority required to submit an amendment to possible ratification there is again some degree of variance in practice to be noted. Minnesota and Arkansas speak of a majority in both houses as being necessary. States requiring a majority vote of all members elected are Arizona, Missouri, New Mexico, North Dakota, Oklahoma, Oregon, and South Dakota. Still others are willing to trust a majority of their elected members, but further add to the procedure provisions intended to strengthen or to clinch, as it were, this action itself. Connecticut allows the first step to proceed from the House of Representatives, but decrees that in the next session two-thirds of both chambers must approve; the primary action by the House is by a majority elected. Indiana, Iowa, Massachusetts, Nevada, New York, Pennsylvania, Rhode Island, Tennessee, Virginia, and Wisconsin stipulate that the proposal must be by a majority vote of all members elected in two successive sessions. Tennessee varies this practice by providing that a two-thirds vote of members elected is necessary to complete the submission during the second of these sessions. Alabama, Florida, Kentucky, Maryland, North Carolina, and Ohio constitute what may be called the "three-fifths" states, although all but North Carolina use the total members elected as the integer measuring their base for the application of this majority. New Jersey introduces another variation; proposal of an amendment to its constitution can be accomplished by either three-fifths of the members of both houses acting in sequence in the same session, or else by the majority of members elected for two successive sessions. The group of the "twothirds-vote" states must now be considered. These are: California, Colorado, Delaware, Georgia, Idaho, Illinois, Kansas, Louisiana, Maine, Michigan, Mississippi, Montana, South Carolina, Texas, Utah, Vermont, West Virginia, and Wyoming. In Delaware if such a measure receives this vote of two-thirds of the elected members, it is deemed a properly adopted amendment. 'Vermont specifies a two-thirds vote of the senate and a majority of the house for the initial suggestion of the amendment in the official sense; this is to be followed by a vote of a majority of all elected members in the succeeding session. ${ }^{12}$

We have thus far paid attention to the matter of the voting majorities required in the various states for the passage of bills into law, for the giving of measures immediate effect by the declaration of an emergency requiring such special effectuation, and in the matter of vetoes. Likewise we have expounded the provisions

\footnotetext{
11 For the details of a great portion of this matter of constitutional amendment, see 8 THE BooK of THE STATES, r950-T95I 88-94.

${ }^{12}$ See the appropriate reference to each state, ibid. Often illuminating variations will be revealed in the footnotes appended to this tabular presentation.
} 
governing the proposal of amendments to state constitutions by legislative action alone. These specified majorities, especially those which are higher than the so-called congressional rule of majority voting, with a quorum present, have significance in relation to the various apportionment and representation systems in vogue within the American states. We shall return to this point after a discussion of state constitutional conventions in relation to this matter of legislative votes and the political and partisan implications of state legislative apportionment.

Thirty-six of the American states make provision in their fundamental laws for the process of calling into being a general constitutional convention to revise their governmental system. While a number of these states provide for the mandatory submission of the question as to whether or not there will be held such a convention, even in those instances it is felt that the legislature still has the discretionary power of action at intervals other than those selected for this compulsory submission of the question. With these mandatory submissions we are not concerned until attention must be paid to the method of organization of the convention. Here we will treat of the provisions relating to the vote by which the question of a call of a convention is submitted to the voters by the legislature.

A simple majority vote of the legislature is specified in Arkansas, New York, Oklahoma, Oregon, and Wisconsin. Majority vote of members elected is the rule in these additional states-Alabama, Kentucky, Tennessee, Virginia, and West Virginia. Nebraska decrees that the vote to submit a call for a constitutional convention must be three-fifths of all members elected to its unicameral senate. With the possible exception of Maryland, which authorizes such action as is here considered by a two-thirds vote of both houses, the remainder of the states stipulate either two-thirds of all members, or the same ratio of all members elected, as being necessary to compass the desired action.

The responsibility of the state legislatures with regard to constitutional conventions is not ended with the matter of submitting to the electorate of the individual states the question as to whether or not such a body shall be summoned. In a large group of states all matters relating to the organization of the convention and the election of members, while largely controlled by precedent and previous practice, are held by the legislature as a discretionary power to be exerted subsequent to the approval of a call for a convention. In others, the general outline of the structure and composition of a constitutional convention is specified in the actual state constitution, and, for the purpose of filling the membership and securing the personnel of such constitutional revisory agencies as these conventions, either causes reliance upon legislative discretion, or else actually employs the going apportionment basis in vogue in the state in question at the time of the summons of the convention. In either event these situations are also fraught with significance in terms of the political and partisan aspects of state legislative apportionment.

Attention will be concentrated in the next few paragraphs on either this matter 
of the relationship of the structure of state constitutional conventions to legislative discretion at the level of decision, or the linkage of convention structure and composition to existing apportionment systems.

Constitutional conventions in California are not to exceed in membership the total of the two houses of that state's legislative body and are to be chosen in the same manner; presumably this means either that the same districts are employed or that such a choice on the part of the legislature implementing this provision would be upheld. ${ }^{13}$ In Colorado such a convention is to be twice the size of the senate and the delegates are to be chosen from the same districts as are the respective senators. $^{14}$ Delaware decrees that two members at large shall be elected from each of the state's three counties, and that one additional member of the convention shall be chosen from each and every representative district of the state. ${ }^{15}$ Any constitutional convention in Florida must be of the same size as the house of representatives of that state, and the delegates are to be apportioned in the same manner as are the members of the house. ${ }^{16}$ The constitution of Idaho, while silent as to the precise mode of the election of delegates to its constitutional conventions, does say that their number must not be less than double the total of the most numerous branch of its legislature. ${ }^{17}$ Illinois utilizes twice the number of its state senators as the measure of the personnel of its constitutional conventions and enjoins the employment of the same senatorial districts as the electoral units for such convention delegates. ${ }^{18}$ Kentucky duplicates the membership total of its house of representatives and prescribes the use of the identical districts in electing its convention delegates. ${ }^{19}$

Maryland requires that there be the same number of convention delegates as the total in the state legislature, and that each representative and senatorial district shall elect the same number as it does in ordinary legislative elections. ${ }^{20}$ In Michigan a constitutional convention will be composed of three delegates elected from each of the state's 32 senatorial districts. ${ }^{21}$ Minnesota enjoins that the desired constitutional convention shall duplicate in membership total and in elective districts the exact setup provided for its house of representatives. ${ }^{22}$ Missouri specifies that ${ }^{2}$ members of its constitutional conventions must be chosen from the state at large; besides these, two shall be chosen from each of the 34 senatorial districts into which the state is divided. ${ }^{23}$ Montana is another state which duplicates its house of representatives in number and apportionment or districting when engaged in constituting a convention to revise its fundamental law. ${ }^{24}$ Nebraska echoes this last stipulation, requiring that its conventions be composed of as many members as its legislature and that they shall be elected from the same districts. ${ }^{25}$

${ }^{13}$ Calif. Const. Art. XVIII, $\$ ₫$, 2; Art. IV, $\$$ I.

${ }^{14}$ Colo. Const. Art. XIX, $\$ 2, \mathrm{r}$; Art. V, $\$ \mathrm{r}$.

${ }^{25}$ Dez. Const. Art. XVI, $\S \S I, 2$.

${ }^{17}$ IDAHo Const. Art. XX, §§' $\mathrm{I}, 3$; Art. III, §ז.

${ }^{10} \mathrm{Kx}$. CONST. $\$ \$ 256,258$.

${ }^{21}$ Mich. Const. Art. XVII, $\$ \S I, 2,4$.

${ }^{2 s}$ Mo. Const. Art. XII, $\$ \S I-3$ (c), Art. III, $\$ \$ 49-53$.

"Mont. Const. Art. XIX, $\$ \$ 9,8$.

${ }^{2 E}$ NEB. Const. Art. XVI, $\$ \S 1,2$; Art. III, $\$ \$ 2,4$.

${ }^{18} \mathrm{FLA}$. Const. Art. XXVII, $\$ \S 1,2$.

${ }^{18}$ ILL. Const. Art. XIV, $\S \S 2, \mathrm{X}$.

${ }^{20} \mathrm{Mr}$. Const. Art. XIV, $\S \S I, 2$.

${ }^{22}$ Mins. Const. Art. XIV, \$\$1, 2. 
Nevada's conventions for constitutional revision cannot have less than the total membership of both houses of its legislature; other details appear to be discretionary. ${ }^{20}$ New Mexico enjoins as many convention delegates as there are members of its house of representatives. ${ }^{27}$ New York prescribes the election of 15 delegates from the state at large, and three additional from each of the state senatorial districts as they may currently be apportioned or established. ${ }^{28}$ Ohio requires the convention personnel to be as numerous as is its house of representatives, but apparently leaves further details to its legislature at the time of the organization of the convention. ${ }^{20}$ South Carolina decrees a personnel for the convention equal to that of its most numerous branch. ${ }^{30}$ Utah carries the same provision into practice except that it demands the total of the seats in its two houses as the measure of the proper membership for its conventions. ${ }^{31}$ Washington reverts to the rule approving the same number as that of its most numerous legislative branch. ${ }^{32}$ With Wyoming we conclude the recitation of this detail; it wants a total in its constitutional conventions equal to its combined legislative memberships. ${ }^{33}$

Now in all this discussion of majorities in legislative action on bills, on matters of immediate effect, on vetoes of any type, on proposals of constitutional amendments, and on submission of calls for constitutional conventions, there should be apparent one factor pertinent to the student of state legislative action. That is the volume of material encountered repeatedly in the mills of state legislation which calls for an extraordinary majority. Undoubtedly the fact that in many states these extraordinary or enlarged, special majorities are constitutionally required exerts a potent influence upon the course of legislative action.

To illustrate this situation practically. In Michigan it is necessary to have half of the membership of the house of representatives, or 50, present as a quorum in order validly to proceed with legislative business. It is necessary to have ${ }_{5} \mathrm{r}$ favorable votes, or a majority of the roo members elected to the chamber, on a measure as a condition precedent to its passage. Should it be desired to give the proposed law immediate effect, then 67 out of the roo elected members must support that action and cohere to bring about that result. Again, if this measure be vetoed, the same 67 house members must be summoned to agree to override that veto, and if it is a question of the proposal of a change in the constitution that same two-thirds of all elected members must conjointly agree.

Under these circumstances apportionment and districting arrangements can achieve a different type of significance and possess diverse implications than in one of the relatively few states relying upon the imitation of the more familiar, more elastic congressional rule-that a quorum being present, a majority of those voting is sufficient to bind the chamber in question. The strategy and logistics of legis-

${ }^{20}$ Nev. Const. Art. XVI, $\S ฐ$, 2; Art. XIX, $\S \S I-3$.

${ }^{27}$ N. M. Const. Art. XIX, $\$ \$ I, 2$.

${ }^{29}$ Ohio Const. Art. XVI, $\S \S I, 2$; Art. II, $\S$ ra.

${ }^{31}$ UTAH Const. Art. XXIII, $\$$ I, 2.

${ }^{28}$ N. Y. Const. Art. XIX, $\S \S 1,2$.

${ }^{30}$ S. C. Const. Art. XVI, $\$ \S I, 3$.

${ }^{33}$ Wyo. Const. Art. XX, $\S \S I, 3$.

32 Wash. Const. Art. XXIII, $§ 5 \mathrm{I}, 2$. 
lation are certainly affected by the requirement of these larger margins of favorable votes so strongly buttressed by constitutional provisions among the various states. Patently it is easier for the legislative strategist or the conniver or manipulator to seek for a majority which may fall as low as 26 out of $5^{\mathrm{I}}$ in a chamber of 100 , if he is following the congressional type of rule, than it is to be faced first with the problem of having a quorum or 50 officially in attendance, with roll calls required on all bills in many states, and then with the question of securing by his endeavors $5^{\mathrm{I}}$ commitments on his side of the issue. To some extent then the connection of this feature of extraordinary majorities in terms of voting behavior in our state legislatures with the separate feature and phenomenon of our apportionment systems can have considerable political significance.

Precisely how this is to be interpreted is subject to conflicting summations. It can be appraised from at least these three ensuing viewpoints, all of which seem to have their merits as interpretations and evaluations of these factors of larger required majorities for legislative decision at the state level. First, we have indicated the increased difficulty in building up agreement and in reaching a compromise upon essential legislative measures, if this must be done against an extraordinary total vote which is specifically required. Thus in apportionments which are grievously out of line in point of time or because of inadequate formulas or because of deliberate adoption of discriminatory systems of districting and apportioning of seats, it may be literally impossible for support to be built up in behalf of legislation desired by the presumably disaffected regions and interests within the state.

On the other hand it may be equally more difficult for persons seeking to perpetrate bad, hasty, and ill-considered legislation, to do so in the face of these retaining walls of specified special majorities, than in the heat and fire of discussion in a chamber but half filled. Patently the swords of controversy are blunted, the fencing foils are tipped, when it is necessary to reckon an absent member as a vote against, and to strive for two votes to offset a vacancy in the complement of the legislature. In other words while the urban areas, or for that matter any sectional faction, cannot, in a legislative system following this and similar practices, get all that they want or even much of it, there is no great chance that they will be seriously hurt or maimed in their operations, for in these latter types of cases the enlarged, specified majority becomes a shield and a buckler to them against too appallingly gross an insult in the political sense.

It is in the third aspect of the problem that the vital difficulty seems to inhere, and it does so in apparent contradiction of the apportionment setup which may be in effect. These required, previously determined, agreement points, so far as decisions upon possible laws are concerned, have the effect of warning all pressure groups, lobbyists of all types, and professional manipulators, of the winning or losing point in terms of that legislative bout. Needless to say this is equivalent to rigging the main event. Hence it is that the veto power of pressure groups can be more 
forcefully brought into play at the level of the state legislatures than elsewhere. Just what part these special majorities demanded by our states as tokens of popular support of legislative enactments and decisions have played in the growth and perdurance of lobbying activities in connection with state legislatures, and what part, major or minor, these more institutionalized lobby groups and pressure machines themselves play in condoning, if not occasioning, lapses and errors in apportionment practice and procedure, merits more investigation because of its own peculiar significance and implications.

The last phase of our inquiry in this second, large, section of this study bore upon the relation of legislatures in the states to the process of constitutional amendment and revision. The analysis contained in the preceding paragraphs will apply with force and emphasis to the matter of the action of such state legislatures in proposing individually suggested changes to the fundamental laws of the states they serve. Comments in succeeding portions of this article will be directed at the obvious significance, in the policy and partisan sense, in continued reliance upon legislative proposal of constitutional amendments exclusively, as is true in some of the American states; at the patent volume of discretionary control which these state legislatures possess in the matter of the submission of the proposed call for a constitutional convention to the voters of the state; and at the fact that many of our states, and a number of those with supposed apportionment difficulties, persist in relating their method of organizing and constructing the personnel complement of their constitutional revisory bodies to the pattern, in terms of mathematics and geography as well as selection, of their ordinary law-making bodies. Surely to continue to do this, or further to seek to do so, is, in terms of apportionment "agues," nothing less than to bed down in a swale full of mosquitos.

The third part into which this article is divided has to do with the results of the referral of certain questions to informed individuals in the various American states. A questionnaire with 6 principal questions was devised and sent out to some 204 persons within these various political units of the United States. Response has been quite heartening, representing over 50 per cent return from the individuals, and covering at least 45 of the states. While quotation will occur in terms of some of the answers, there will be no specific indentification of the correspondents other than to say that they included legislators, public officials, political scientists, publicists, and personal friends believed to have judgment and the ability to exercise it. The author is grateful to all for their assistance.

The first question was this. In your opinion which of these factors occasions most frequent controversy in your state with regard to legislative apportionment? Check these from $I$ to 6 in order of significance. The factors listed were the following:

Number of chambers

Size of houses

Frequence of apportionment
Representative basis

Fairness of districting

Apportioning agency 
The answers of the correspondents rated these factors in order of their significance as follows: first, fairness of districting; second, representative basis; third, frequence of apportionment; fourth, the matter of the apportioning agency; fifth, the size of the various branches or houses of the legislature; and sixth and last, the matter of the number of chambers.

Table I reproduced immediately below will give the distribution of the weightings from those indicating such on each of these items.

TABLE I

\begin{tabular}{c|c|c|c|c|c|c}
\hline \hline Item & First & Second & Third & Fourth & Fifth & Sixth \\
\hline Number of chambers.......... & 3 & 1 & 8 & 9 & 9 & 55 \\
\hline Size of houses.............. & 3 & 10 & 6 & 21 & 40 & 5 \\
\hline Frequence of apportionment.. & 8 & 13 & 20 & 23 & 11 & 10 \\
\hline Representative basis........ & 29 & 30 & 22 & 6 & 3 & 0 \\
\hline Fairness of districting........ & 54 & 30 & 7 & 4 & 3 & 1 \\
\hline Apportioning agency......... & 0 & 11 & 20 & 20 & 18 & 14 \\
\hline
\end{tabular}

The second question was drafted as follows. In your opinion is your state's legislative apportionment productive of significant controversies in the political sense...

Between major political parties..................... Nes No

Between rural and urban areas...................... Nes No

Between geographical regions without regard to urban or rural distinctions......................... Nes No

Between metropolitan and non-metropolitan areas........... Yes No

Between labor and business interests................... Nes No

Between parts of metropolitan areas.................. Yes No

Needless to say the replies to these were distinctly interesting. On the question as to controversy between political parties over legislative apportionment, the answers were: yes-43; no- 57 . In terms of agreement among the replies this is the tale. All correspondents from Alabama, Colorado, Delaware, Georgia, Idaho, Indiana, Iowa, Kansas, Louisiana, Maine, Maryland, Mississippi, Nebraska, North Carolina, North Dakota, Oregon, South Carolina, Tennessee, Texas, Utah, Vermont, West Virginia, and Wyoming agree that apportionment does not, produce controversy between their political parties. Equally certain that it does are all the correspondents from California, Florida, Massachusetts, Michigan, New Hampshire, New Mexico, Pennsylvania, Rhode Island, South Dakota, and Wisconsin.

Division in the views of the informants was apparent in the following states: Illinois, Connecticut, Kentucky, Minnesota, Missouri, New Jersey, New York, Ohio, 
Oklahoma, Virginia, and Washington. Montana and Nevada were neither heard from nor was material at hand from which to deduce a possible answer.

The rural-urban cleavage was recognized almost unanimously as occasioning apportionment arguments and controversies. Ninety-four correspondents agreed that this was a prime factor, while only 9 felt that it was of no importance whatsoever. The states where it was the opinion of all informants that this issue did not occasion controversy in the apportionment sense were Kentucky, Idaho, Mississippi, and South Dakota. Information was lacking here from North Dakota, Montana, and Nevada.

The third of these subsidiary questions relating to the occasion of controversy over apportionment had to do with the matter of geographical or sectional cleavage without regard to urban or rural distinctions. Here the replies ran as follows: yes -46 ; no- 49 .

Affirmative agreement as to the presence of these sectional or geographical factors operating upon the apportionment problem came from all respondents in Florida, Iowa, Kansas, Delaware, Mississippi, Nebraska, New Hampshire, New Mexico, North Carolina, South Carolina, South Dakota, Tennessee, Texas, and Washington. Only negative replies came from this group of states: Arkansas, Indiana, Louisiana, Maine, Massachusetts, Minnesota, Missouri, Rhode Island, Vermont, and Virginia.

Sharper divisions of opinion came from the informants in these states: Arizona, California, Georgia, Idaho, Michigan, Illinois, Kentucky, New York, Ohio, Oklahoma, Oregon, Pennsylvania, Maryland, Utah, Wyoming, Wisconsin, and West Virginia. For the other states not listed here the information was either inadequate or completely missing.

The fourth subsidiary point was that of cleavage between metropolitan and nonmetropolitan areas. This factor received substantial recognition as one occasioning strife over state legislative apportionments. Sixty-seven responses were affirmative, while 32 were listed as negative. The only states from which there was a reply unanimously in the negative were these: Vermont, Rhode Island, Louisiana, Arkansas, Tennessee, New Hampshire, Mississippi, Idaho, Arizona, Delaware, and Colorado.

The fifth sub-question involved the decision as to whether stress and tension between labor and business interests entered into the apportionment complex of the states. Here only 22 affirmative replies were received as against 69 nays. Arizona, California, Connecticut, Maryland, Nebraska, New Jersey, Oregon, Rhode Island, Tennessee, and Wisconsin appear to be the states in which cleavage between labor and business has significance in terms of apportionment. In another large group of states there occurred division of opinion among the correspondents who answered. This latter group of states included: Indiana, Iowa, Michigan, Minnesota, New York, Ohio, Utah, West Virginia, and Washington.

The sixth and last of the subordinate queries within this second question sought 
to focus attention upon a phenomenon which seems to be developing within some states and seems to have import for the student of state legislative arrangements. in the future. That is the incipient, and as yet oftentimes latent, hostility and cleavage within metropolitan regions in terms of portions thereof.

Only I6 affirmative reports were noted as against 80 negative replies. The affirmative answers came from Arkansas, Pennsylvania, Massachusetts, Maryland, California, Arizona, Wisconsin, Oregon, Michigan, Minnesota, New York, Washington, and Ohio. Seldom were the responses in these states in agreement and it can be noted that there is a certain awareness of this newer type of intra-metropolitan area: strain but time has not permitted it to develop to the point where it has become a factor in state legislative apportionment.

The third principal question submitted to these informants was this. In your opinion does your state legislative apportionment figure as an issue in the following situations...
I. Labor and management..........................
No
2. Support of public education..................... Yes
No
3. Highway fund distribution..................... Yes
No
4. Local government subsidies and support............... Yes No
5. Social welfare programs....................... Yes No
6. Taxation and public finance...................... Nes No
7. Legislative organization itself.................... Nes No
8. Imbalance of party strength...................... Nes No

On the first point, that of labor and management and the connection of state legislative apportionment as an issue in that situation, the replies were: $25-y e s ; 68-$ no. In general the suggestion of such interconnection of this factor of apportionment with the issue of labor and management came from the following states: Arizona, California, Florida, Georgia, Idaho, Indiana, Iowa, Maryland, Michigan, New Hampshire, Ohio, Oklahoma, Oregon, Rhode Island, Tennessee, Utah, and Washington. It would appear also that there was some evidence to support similar conclusions as to New Jersey and Connecticut.

The second subordinate point was that of support of public education. Here $5 \mathrm{r}$ informants argued that this involved the apportionment issue and 43 were likewise certain that it did not. States in which all correspondents agreed on an affirmative stipulation were Arkansas, Delaware, Wisconsin, Kansas, South Carolina, Arizona, Florida, Nebraska, Iowa, New Hampshire, and 'Tennessee. 'The states where all' responses were negative were Colorado, Mississippi, Louisiana, South Dakota, Alabama, Kentucky, Virginia, Idaho, and Rhode Island, although the last was qualified by the phrase "not openly." The distribution here would indicate a rather strong linkage of apportionment and its significance in terms of the support of public education.

Highway fund distribution was the third sub-head. Here 66 informants voted that it was an issue in connection with apportionment; 30 were of an opposite 
opinion. Areas of complete agreement as to the validity of the apportionment problem as an issue in connection with the highway fund distribution were found in Washington, Oklahoma, Ohio, Maryland, New Mexico, Minnesota, Arkansas, Wisconsin, Kansas, South Carolina, Arizona, Florida, Nebraska, Iowa, New Hampshire, Tennessee, Mississippi, and Colorado. In other words in 18 states the issue was sufficiently keen that all persons queried agreed in relating it to the problem of apportionment. At the opposite extreme the states of Oregon, Delaware, Louisiana, South Dakota, North Dakota, Alabama, Kentucky, Virginia, and Rhode Island disavowed such interconnection of these twin problems-apportionment and highway fund administration. Since only 9 states seemed to indicate that it was not an apparent issue, the conclusion must be that this is one of the more general sources of difficulty and therefore of significance in terms of partisan and political implications of state legislative apportionment.

Local government subsidies and support produced 55 affirmativés and 39 negatives. States in which there was a clear affirmation of the presence of this divisive issue were Arizona, Maine, Indiana, Ohio, Maryland, Minnesota, Wisconsin, Kansas, South Carolina, Nebraska, New Hampshire, Colorado, Delaware, and Rhode Island $\mathrm{-r}_{4}$ in all. Denials of the presence of the same issue came from the following states: Arkansas, Tennessee, Mississippi, Oregon, Louisiana, North Dakota, South Dakota, Alabama, Kentucky, and Virginia. The remaining 22 states from which replies were received were divided in their answers, but at least indicated the presence to some degree of the particular problem being probed.

We come now to the relation of social welfare programs to apportionment. This time only 43 yeas were noted as against 50 negatives. States where all replies were in accord affirmatively were Florida, New York, Kansas, South Carolina, Nebraska, New Hampshire, Delaware, and Mississippi. Negative responses were received uniformly from Iowa, Pennsylvania, Oklahoma, Utah, Maine, Colorado, Rhode Island, Arizona, Arkansas, Tennessee, Oregon, Louisiana, South Dakota, Alabama, Virginia, and Kentucky.

Next in line for consideration is the matter of taxation and finance. Fifty-seven replies indicated the belief that these issues figured in connection with apportionment in affecting the politics of the state of the respondees. Thirty-seven did not consider it to be so; thus the split here was 57 to 37 . Entirely affirmative were the answers from these areas: Alabama, Arizona, Maine, Iowa, Delaware, Mississippi, New Hampshire, Nebraska, South Carolina, Kansas, Florida, Washington, Michigan, Indiana, Minnesota, and Wisconsin-16 states. On the completely negative side of this sub-question were: Idaho, Oklahoma, Utah, Colorado, Rhode Island, Arkansas, Tennessee, Louisiana, South Dakota, Kentucky, and Virginia. Eleven states made up this group. Nineteen remaining states gave divided replies indicating the presence in some degree of this problem of taxation connected with apportionment.

For the last two subordinate questions emphasis was placed upon matters of 
legislative organization and on party strength as reflected within the legislature. The first was the role and effect of legislative apportionment as it affected the problem of legislative organization. On this the replies divided as follows: 68 yeas, 29 nays. The following states reported in the negative with uniformity-Maine, Delaware, Nebraska, South Carolina, Colorado, Idaho, Rhode Island, Tennessee, Louisiana, and Virginia. Divided returns came in from Kansas, Washington, Minnesota, Oklahoma, Kentucky, New York, West Virginia, Georgia, Missouri, Wyoming, Illinois, Texas, North Carolina, Vermont, and Massachusetts. There are I5 instances of such divided or disagreeing returns. The remaining $2 \mathrm{I}$ states which made definite answer said that their internal organization was affected by the factor of legislative apportionment when their law-making bodies undertook to set their procedure in motion.

The last of these subordinate questions sought to ascertain whether there was evidence that existing apportionment schemes made for a practical imbalance or inequitable distribution or representation of party strength. The overall summation of replies was 55 yeas to 43 nays. There would seem to be an imbalance or underrepresentation of party divisions throughout the state by reason of the workings of the apportionment systems in these states: Pennsylvania, Oregon, Wisconsin, Indiana, Michigan, Florida, New Hampshire, Rhode Island, Tennessee, Virginia, Kansas, Washington, New York, Illinois, Massachusetts, Connecticut, and New Jersey. Difference of opinion as to the degree of imbalance of party representation or strength arises or is expressed in a number of states-Ohio, California, New Mexico, Iowa, Maine, Oklahoma, Kentucky, Missouri, Georgia, Wyoming, and North Carolina. It would appear that there is some degree of under-representation of some party to be found in at least 28 states. On the basis of the negative replies, these states would not seem to face this problem in the partisan sense-Maryland, North Dakota, South Dakota, Arkansas, Utah, Mississippi, Arizona, Alabama, Delaware, Nebraska, South Carolina, Colorado, Idaho, Louisiana, Minnesota, West Virginia, Texas, and Vermont. Again Montana and Nevada are missing.

The fourth principal question was worded as follows. Have any of the following changes been proposed in your state in the last ten years? Check those which have.

Single house legislature Automatic apportionment

Straight population as basis for both cham-Shift to voting performances as basis for bers representation

So-called federal plan, with area representa-Specific mandamus provisions applicable to tion, in one chamber apportionment

The replies to this question can be summarized by means of Table II.

From the data below it appears that the ideas for improvement in apportionment mechanics which have been most popular have largely followed one or the other features of a general pattern. If the legislatures do not of themselves apportion, let there be transfer to some other authority so that mandamus does apply. If nothing 
else will suffice, change to a single house legislature. In that event an apportionment does have to occur.

The fifth principal question was one devised to try to elicit evidence as to whether or not the conflicts and controversy in terms of apportionment arrangements and representative systems at the level of the American states symbolized deeper cleavages than those merely displayed by legislative roll call divisions and party affiliations. The precise text of the question will be reproduced at this point. It read: Is legislative apportionment, in your state, symbolic of cleavages sharp and decisive in other relations than legislative behavior and votes themselves?

There were 52 yeas, to 52 nays. Affirmative answers came in from the following states in all instances: Delaware, Nebraska, Alabama, Oregon, Wisconsin, Indiana, Colorado, South Carolina, New Hampshire, Florida, Mississippi, Arkansas, Massachusetts, Maryland, Maine, New Mexico, and California. Sometimes there were added comments from these $I 7$ states. Thus there are references to the pervasive ruralurban cleavage in some of these states as in Alabama, and to the economic cleavages within Maryland and Delaware. Influences of dairy and cattle producers are noted in Oregon and in Nebraska as deeply seated factors which are exemplified or symbolized by legislative conflict.

The negative tally is complete and total in these states: Vermont, North Dakota, Wyoming, West Virginia, Minnesota, Louisiana, Idaho, Rhode Island, Utah, Tennessee, Virginia, Kansas, and South Dakota.

Conflicting answers were received from a substantial number of states which included Michigan, North Carolina, Pennsylvania, New Jersey, Connecticut, Texas, Arizona, Washington, New York, Illinois, Ohio, Missouri, Georgia, Kentucky, Oklahoma, and lowa. Again Montana and Nevada were missing.

So we come to the sixth and last principal question. It was this. Would there be significant changes in the political complexion and policy in your state were an actually equitable apportionment in theory and practice obtained? Opportunity for longer comment was provided here as was also the case in the other questions, although an extensive explanation was not expected elsewhere.

In terms of the overall summary, there were 65 positive answers to this question, 28 negative ones, and 8 were necessarily described as "qualified." The location of these replies from the standpoint of their state of origin will be summarized. Uniform affirmative answers were received from the various correspondents in these 
states; Delaware, Alabama, Oregon, Wisconsin, Indiana, Colorado, South Carolina, New Hampshire, Mississippi, Massachusetts, Arkansas, Maryland, Kansas, Maine, Florida, Michigan, Washintgon, Ohio, and New Mexico. Prevailingly negative answers came in from these particular states-Nebraska, West Virginia, Louisiana, Idaho, Rhode Island, Utah, Tennessee, South Dakota, North Dakota.

While the larger group of answers from this next list of states were indicative of the probability of change, they were not reported as such unanimously; there were dissents. These were the states in this group: Connecticut, New Jersey, Minnesota, Virginia, Iowa, Oklahoma, Kentucky, Georgia, Missouri, North Carolina, Pennsylvania, Texas, Arizona, New York, California, and Wyoming.

Now, what are the types of changes which are believed by these informants as likely to occur? Obviously these comments must be drawn from those who expressed a conviction that a change in apportionment would produce results of significance in terms of political composition of the state. Thus from California, Michigan, Iowa, and Minnesota comes the indication that the Democratic-liberal and labor forces of the state would gain power and influence. In Alabama there is not likely to be any change in party composition, which considering the present alignments is not surprising. However, the same increase in the strength of organized labor is looked for along with a decrease in the trend toward ultra-conservatism, and carried along with these would be increased support for programs favorable to urban and industrial areas. Emphasis upon rural problems would decrease in Alabama, it is felt. Delaware reports that changes probably would take place with respect to taxation and with regard to welfare programs. In Florida such an apportionment as is visioned here would change the balance from north and west to the center and south. It would affect tax distribution, and favor the reorganization of the executive branch and the general revision of the constitution. It is felt that Georgia would be more progressive minded if the urban areas of the state had more representation. Decided shifts in partisan influence and toward metropolitan control of public affairs would undoubtedly occur in Illinois.

While no apparent change in party control would occur in Maine, it is the opinion there that changes in party attitude and program would follow such an apportionment. Maryland sees some changes occurring within the dominant party, and there is reason to hope for more local home rule under such circumstances. From Massachusetts comes this comment: a redistricting with only small changes would totally change the political alignment in Congress and in the legislature.

Missouri suggests that there might result some strengthening of unions, a buttressing of the urban groups in both parties, and a change in the emphasis of highway programs together with an increase in grants-in-aid and permissive legislation to cities. Labor and the Democratic party would certainly gain in New Hampshire. New Mexico correspondents stress the effect of the 1948 apportionment in changing the general bias of that state's politics, giving it a slightly different racial and re- 
ligious aspect than formerly. Again in Ohio there comes the connection between urban gain and benefit to the Democratic party; however there is doubt as to whether there would be improved legislative-executive relationship even under these conditions.

Oregon might see a growth in Democratic strength in the legislature, which would also be pro-labor and pro-metropolitan in character. However hints that there are possible internal cleavages within Portland militates against a full exploitation of this conclusion. South Carolina sees the possibility of constitutional changes being more readily secured were the legislature equitably apportioned. Texas cities would have greater influence as well as the newer areas of the state in terms of development and population growth. It is felt that this would not alter greatly the essentially conservative complexion of the Texas legislature. Different apportionment patterns in Vermont could lead to change in many of the more peculiar and local of her political customs, but apparently would not greatly alter policies or programs nor touch the element of party control. Reapportionment on a more strictly population basis would increase the forces of the liberal wing of Virginia politics but it again is doubtful if there would be any great or lasting significance in this fact. Washington and Wyoming would look for a reenforcement of a liberal orientation with the specified type of equitable apportionment. Such is the general trend of the comments as to the possibilities of change were equitable apportionments attainable, and as to the character of the changes themselves as they seem to be indicated by the tendencies of today.

By the very nature of the position, a representative who serves in a lawmaking body within the communities of the United States is distinctly and ineradicably political in character. This simple, elemental fact makes any attempt to scatter a given number of these individual representatives throughout any state, political in character, because of its nexus with the art and action of policy determination or legislation when this function is devolved upon an elected legislative assembly and not localized elsewhere within the bounds of American government. Let it be recognized that any legislator and any legislative apportionment under the most ideal of conditions will be political.

In Midsummer Night's Dream, Shakespeare has one of Bottom's companions utter the prescient words "This lantern doth the horned moon present." Representation and apportionment partake of the same character; unable to bring the horned moon to hand, the crude rustics and louts of Shakespeare's immortal creation, seized upon that which was at hand which had somewhat of the character and nature of the moon-a lantern which too could give light under certain conditions and circumstances. Unable to bring the whole people for whom the law is to be made to bear upon the decision of particular problems, man has seized upon the institution of the representative assembly and made it both the horned moon of the 
vox populi and yet the lantern as well because it too gives light upon the paths of social control and action.

There are three developing factors which may occasion some change in the setting and the lines of the drama of legislation at the plane of the American states. The first is simply the lessening value of any distinction between rural and urban as a means of measuring cleavage and indicating types of stress and strain in terms of ecological reactions. Are not American communities becoming of a character where the basic question is no longer whether each is urban or rural, but rather how each is urban in a. different way from that in which a comparable community is also urban-where all these communities are distinctly characteristic of a civilization which thinks in urban terms even to the point of jealousy and envy over themselves and their likes? How will this expanding universe of the urban affect the problem of the representative assembly and its apportionment?

Closely related to this problem is the increasing recognition of the fact of extreme mobility on the part of the American people, and the rise of the condition of Anomie or non-belonging. What significance has representation unless there is a sense of community, unless what Krabbe called the feeling for right of the community, works in and through as well as for those who compose it? Can censuses continue to be adequate for apportionment bases in the face of this modern nomadism expressed by this hectic motion to and fro from place to place? Must we not search for a new measure of population distribution for apportionment purposes in the kinetic form of voting performance in a manner which will still preserve in government the power to act?

Lastly, there is hope in the emphasis upon revitalization of our state legislatures through the trend towards annual sessions, in the drive for increased salaries for members, in the concern for the development of staff agencies and programming units such as legislative councils and reference services, in the realization that in the past much has been done to keep the state legislatures as a group from an effective partnership and place in the process of government; a hope that in the wake of such reworking of our state legislatures awareness may come of the outmoded "lanthorn" which will be followed by action on the part of these bodies themselves tantamount to a transformation of them into the most effective of modern electric lights.

In a democratic community believing in representative assemblies all the stuff of government and public policy are caught up into the symbols and the artistic configuration of legislative construction. Representative government will adapt its pattern if the American states continue to deserve that form of government; if the people cannot make it work, then in John Stuart Mill's words, it may be better than they deserve. 